\title{
The Importance of the Similarity of Profiles of Companies-Partners in the Process of Post-transaction Integration
}

\author{
Anna Stankiewicz-Mróz \\ Lodz University of Technology, Lodz, Poland
}

\begin{abstract}
The aim of this article is to find an answer to the question: Does the similarity of the profiles of companies participating in the acquisition influence the post-transaction integration? While creating a research concept, a hypothesis was adopted that the range and the dynamics of the post-acquisition integration are higher, if the companies are similar as far as their sizes, structures, life cycles, and organizational cultures are concerned. Five acquisitions from the pharmaceutical sectors were examined. The results presented in this paper are a part of wider research on consolidation processes in the pharmaceutical branch. In each case, the research had a retrospective character. In order to assess the integration activities, the research was conducted three years after the transaction. An inductive analysis of case study type was used and the technique of research triangulation was applied. A part of the research used for the needs of this paper was conducted by the means of two methods: individual in-depth interviews with the presidents/managing directors of the companies which were taken over and panel interviews in which the presidents and managing directors as well as director and managers of the development units, managers of organization as well as the directors/managers of human resource units of the acquired companies participated. The analysis of the profiles of similarity of companies-transaction partners showed that although they belonged to the same branch, the analyzed companies are characterized by a low level of similarity, especially as far as the structures and organizational cultures are concerned. The strategy of functioning after the merger is based in the majority of cases on the model of partnership. It takes for granted a low level of integration referring only to some selected areas and is connected with an adoption of a long-term integration perspective foreseen for a period longer than three years of functioning in the merged structure.
\end{abstract}

Keywords: acquisition, profile of similarity, pace and range of integration

\section{Introduction}

From the point of view of the final success of the acquisition transaction, a phase of the post-transaction integration is a key stage of the process. It is often considered to be a lever important for generating values in the processes of mergers and acquisitions (Habeck, Kröger, \& Träum, 2000; Agrawal \& Jaffe, 2000) and the most important determinant of the synergy of acquisitions (Larsson \& Finkelstein, 1999). At the same time

\footnotetext{
Anna Stankiewicz-Mróz, Ph.D., Faculty of Organization and Management, Department of Management Systems and Innovations, Lodz University of Technology, Lodz, Poland.

Correspondence concerning this article should be addressed to Anna Stankiewicz-Mróz, Piotrkowska 266, 90-924 Lodz, Poland.
} 
integration is among the most risky stages of the whole transaction (Habeck et al., 2000) and at the same time the most expensive one. Coffey, Garrow, and Holbeche (2002) underlined that the most common mistake is to assess the value of the acquired resources without taking into consideration the real costs of integration. Pablo and Javidan (2002) noticed that the integration is connected with the introduction of changes in all the areas of functional activities, organizational structures, systems, and cultures which merge within a company in order to help them to consolidate in one functioning totality.

Epstein (2004) noticed that a coherent integration strategy is one of five key elements deciding about the transaction's success which defines the frameworks for the activities of the organization in the new merged structure. The similarity of both internal and external organizational values of the merging companies (e.g., the similarity of organizational cultures, technologies, products, or sizes of organizational structures of companiestransaction partners) is one of five key elements which decide about the transaction success. The research pointed at the differences among the merging companies as one of the most common reasons of failures at the stage of integration. These differences refer to organizational cultures, implemented development strategies, applied techniques and production technologies, information systems, and applied operational procedures in single areas of activities.

The aim of this paper is to draw the attention to the issue of the similarity of the organizational profile of the merging companies as to the factor which may influence the integration process and first of all its range and dynamics. As the research shows, a proper level of similarity among the transaction partners influence, e.g., the improvement of the coordination of the processes of cooperation among the stakeholders (Petuzzelli, Albino, \& Carbonara, 2009), is favorable to innovativeness and limits the feeling of uncertainty (Boschma, 2005).

\section{Literature Review}

The issue of the companies' similarity can be considered by the prism of the paradigm of organizational proximity defined in the area of management sciences, described in details in the works of, e.g., Rallet and Torre (1999), Torre and Rallet (2005), Torre and Gilly (2000), as well as Menzel (2006). Boschma (2005) distinguished five levels of proximity:

- geographic - a small space distance or time difference (mesostructural level);

- organizational - a similarity of external and internal organizational conditions (mesostructural level);

- cognitive - convergence of knowledge bases, reference bases, and technology (mesostructural level);

- institutional-functioning in the same institutional surrounding (microstructural level).

As Cooke (2006) noticed, a proximity is a measure of easiness in communication, exchange, and cooperation which is done among the interested stakeholders of the defined space. Czakon (2010) underlined that it can result from the convergence of the "physical space, psychological, and social relations as well as shared cultural values or institutional conditions of operation". Therefore, the organizational proximity can be perceived by the prism of two partially complementary and partially substitutive notions (Torre \& Rallet, 2005):

- logics of belonging: The members of the organizations are "close" to one another, because between them, there are many common and repeated interactions additionally strengthened by the rules and routine which are a consequence of the permanent cooperation;

- the logic of similarity: The units are perceived as close to one another, because they are the same or using a colloquial expression they are "cut from the same cloth". This logic refers to a common system of values for 
the specific members of the same organization, which strengthens their capacity to cooperate. The similarity of the organization using the logic of similarity increases the convergence of the organization. A common cultural context has a key meaning in the process of creating the awareness "us", creates a bases for creating the trust (Zeller, 2004), and can be a basis on which the process of the post-transaction integration can be based.

Dimensions of similarity of the organizational profiles and their meaning for the process of post transactional integration are presented in Table 1.

Table 1

Dimensions of Similarity of the Organizational Profiles and Their Meaning for the Process of Post Transactional Integration

\begin{tabular}{|l|l|}
\hline Dimensions of proximity & Potential meaning for the process of integration \\
\hline Geographic & A bigger possibility of direct contacts among the transaction partners. \\
\hline Organizational & $\begin{array}{l}\text { A convergent approach to management; a similarity of the strategic orientation, a philosophy of } \\
\text { activities, organizational culture, and structure. The similarity in this dimension can be a basis of } \\
\text { creating a trust among the organizations and for a smaller risk of conflict behaviours. }\end{array}$ \\
\hline Social & $\begin{array}{l}\text { Interpersonal relations which connect the employees of the merged organizations; the similarity of } \\
\text { norms and values; a bigger likelihood of effective communication; and a smaller risk of conflict behaviours. }\end{array}$ \\
\hline Institutional & $\begin{array}{l}\text { Companies operate in the same organizational environment and for this reason there are the } \\
\text { frameworks which facilitate the mergers and integration. }\end{array}$ \\
\hline Cognitive & $\begin{array}{l}\text { A convergence of technological solutions, applied standards of production, and quality norms; a high } \\
\text { effectiveness of the communication among the organizations thanks to a common language in the } \\
\text { whole branch. }\end{array}$ \\
\hline
\end{tabular}

Source: Own preparation on the basis of Boschma (2005).

In the processes of mergers and acquisitions, the similarity on the mesostrucural level is particularly important which translates into an easier cooperation due to a convergence of the approach to management, philosophy of acting, structure and organizational culture, or a strategic orientation. The diagnosis of the level of similarity of companies on the mesostructural level can be used as a tool for decreasing the transaction risk (Stankiewicz-Mróz, 2012). Generally while taking the decisions referring to the adoption of a specific integration strategy, a few factors are taken into consideration (Aniszewska, 2002):

(1) kind of capital management: The integration process depends on whether it is a merger or an acquisition;

(2) sources of values in the acquired company: In this place, the following question should come back: What is a real aim of the acquisition of the given company (know-how, market shares, or, e.g., unique technologies and so on)?

(3) integration aim which defines a level of strategic and organizational dependence or autonomy of the merging organizations;

(4) opinions of stakeholders (e.g., stakeholders interested in quick financial effects);

(5) social and legal commitments: They are a consequence of the binding Labor Law provisions but also of certain regulations (e.g., functioning in the company-aim of the acquisition and social contracts known as social packages);

(6) organizational proximity on the mesostructural level that is a similarity of internal and external organizational values of the merging companies (e.g., a similarity of the organizational cultures and the sizes of the transaction partners).

\section{Methodology}


The research was conducted in five deliberately chosen companies of the pharmaceutical sector which were taken over in the years 2008-2010. It was conducted in two stages: the main one (years 2011-2012) and the complementary one (in the year 2013). In order to evaluate the integration process, a conviction was adopted that one of the criteria of choosing a sample was a requirement that the transaction could not be conducted earlier than three years before. Such time perspective allows evaluating the results of the implemented integration activities. The research was based on the qualitative case study method. In the literature, the relevance of the usage of qualitative methods is underlined.

Miles and Huberman (1994) suggested that in case of the research on acquisition and mergers, there is a need of a deep understanding and contextualization and therefore qualitative research methods are optimal. A similar approach is presented by Larsson and Lubatkin (2001) who underlined that qualitative research is really suitable for the research on mergers and acquisitions, because of the need of detailed context descriptions of the sensitive data. Bower (2004) and Hunt (1990) pointed at a need to use case study methods in order to conduct research on mergers and acquisitions. As Bengtsson and Larsson (2012) noticed, the research with the usage of case study has a unique value in case of mergers and acquisitions, as they allow understanding a complex combination of factors accompanying first of all the integration processes allowing capturing its multidimension.

A part of the research used for the need of this paper was conducted using two methods: individual in-depth interviews with presidents/managing directors who run the acquired companies or focused group interviews in which presidents/managing directors participated as well as directors/managers of development units, directors/managers of economic departments, and organization managers and directors/managers of human resources departments of the acquired organizations. Hess (1968) underlined the positive effects of a focused interview and put the advantages in five-S formula: synergy, snowballing (the effect of a snowball referring to the answers of respondents), stimulation, security (security which is assured by the presence of other participants of the meeting), and spontaneity (spontaneity of behavior) (Larsson \& Lubatkin, 2001). This technique is particularly dedicated to conducting research with retrospective character. Although as Barbour (2011) noticed, a possibility to get the results very quickly is a very big advantage of focus research while conducting the aforementioned research, the basic problem was to gather a panel group. For this reason, although the schedule of conducting the research was defined two to three months earlier in one case, there was a need to modify the agreed dates.

\section{Empirical Results}

During the interviews, the respondents have defined a level of similarity of companies in the moment of transactions in the following areas:

- sizes of the companies participating in transactions (measured taking the size of the employment into account);

- capital resources;

- market shares;

- general financial situation;

- a level of product and technological similarity;

- a similarity of the organizational structures (leanness, range of management, centralization, formalization, and specialization); 
- life cycle of organization;

- organizational culture;

- style of management.

The organizational culture, diagnosed on the basis of the respondents' evaluation of its 10 dimensions (Table 2) was the parameter analyzed very deeply. As the effect, it was possible to define a profile of the convergence of acquisitions partners in the field of culture. It must be underlined that the organizational culture in case of acquisitions is treated as a main success factor which exerts a significant influence on the process of implementing changes and is also a factor determining the productivity and it influences significantly the effectiveness of the acquisition (Iwai, 2002). The research showed that almost $60 \%$ of the examined companies underline that the cultural convergence of both companies is a success factor in acquisition transactions. For this reason, it seems that the cultural audit within which the depth of the cultural differences and the risk for the transaction process are related to this is an important activity already at the due diligence stage.

In case of the existence of big cultural differences between the two companies, the board of the merged company should treat a definition of the new organizational culture as their priority during the integration process.

Table 2

Features of the Organizational Culture of the Analyzed Companies, Partners of Acquisitions

\begin{tabular}{|c|c|}
\hline Dimension identifying culture & Characteristic \\
\hline \multirow{2}{*}{ 1. Character and range of control } & Tight \\
\hline & Flexible \\
\hline \multirow{2}{*}{ 2. Standards of activities } & Needs of clients \\
\hline & Procedures \\
\hline \multirow{3}{*}{ 3. Generating willingness to take risk } & Low \\
\hline & Moderate \\
\hline & High \\
\hline \multirow{2}{*}{ 4. Level of specialization } & Narrow \\
\hline & Wide \\
\hline \multirow{2}{*}{ 5. Character of relations } & Hierarchical \\
\hline & Partner \\
\hline \multirow{3}{*}{ 6. Flexibility } & Low \\
\hline & Moderate \\
\hline & High \\
\hline \multirow{2}{*}{ 7. Character of work organization } & Individual \\
\hline & Team \\
\hline \multirow{2}{*}{ 8. Character of communication } & One-way \\
\hline & Two-ways \\
\hline \multirow{2}{*}{ 9. Range of freedom } & Pressure on formal rules \\
\hline & Autonomy \\
\hline
\end{tabular}


10. Character of leadership in case of changes

Model of a craftsman ${ }^{1}$

Model of a star

A profile of the similarity of transaction partners in the selected areas at the beginning of the transaction is presented in Table 3.

Table 3

A Profile of the Similarity of Transaction Partners in the Selected Areas at the Beginning of the Transaction

\begin{tabular}{|c|c|c|c|c|c|}
\hline \multirow{2}{*}{$\begin{array}{l}\text { Areas of the analysis of the } \\
\text { similarity of organizational profile }\end{array}$} & \multicolumn{5}{|c|}{ Level of similarity among the transaction partners } \\
\hline & Transaction 1 & Transaction 2 & Transaction 3 & Transaction 4 & Transaction 5 \\
\hline Size & Low & Low & Low & Low & Low \\
\hline Capital resources & Low & Low & Low & Low & Low \\
\hline Similarity of technology & Low & High & $\begin{array}{l}\text { Acquiring company } \\
\text { cooperated earlier with the } \\
\text { acquired company } \\
\text { (contracted the production) }\end{array}$ & Low & Moderate \\
\hline Similarity of served markets & Moderate & Low & Moderate & Moderate & Low \\
\hline Similarity of products & Moderate & High & Low & Low & Low \\
\hline Market share & Low & Low & Low & Moderate & Low \\
\hline Sales value & Low & Low & Low & Low & Low \\
\hline Similarity of organizational structure & Low & Low & Low & Low & Low \\
\hline Organizational culture & Low & Low & Low & Low & Low \\
\hline Lifecycle phase & Low & Low & Low & Low & Moderate \\
\hline Style of management & Moderate & High & Low & Low & Moderate \\
\hline General financial situation & Low & High & Low & Moderate & Low \\
\hline
\end{tabular}

In the examined organizations, the structure consists of two parts with a different characteristic. On one hand, there is a stable part with hierarchical relations within which the routine work is done (production area) and on the other hand, there is a flexible part, with a flattened organizational structure in the field of " $R+D$ ".

Profile of organizational similarity of the transaction partners versus a level, range, and pace of integration is presented in Table 4.

Table 4

Profile of Organizational Similarity of the Transaction Partners Versus a Level, Range, and Pace of Integration

\begin{tabular}{|l|l|l|l|}
\hline $\begin{array}{l}\text { Number of } \\
\text { transaction }\end{array}$ & $\begin{array}{l}\text { Level of } \\
\text { organizational } \\
\text { similarity }\end{array}$ & Areas which were integrated & Level, range, and pace of integration \\
\hline Transaction 1 & Low & $\begin{array}{l}\text { - Organizational structure; } \\
\text { - Partial IT integration; } \\
\text { - Distribution channels; } \\
\text { - Sales integration; } \\
\text { - Accounting procedures; }\end{array}$ & $\begin{array}{l}\text { - Range: partial integration; } \\
\text { Level: moderate; } \\
\text { Pace: integration planned for the period } \\
\text { of three to four years, with one year } \\
\text { transition period. }\end{array}$ \\
\hline
\end{tabular}

\footnotetext{
${ }^{1}$ Craftsman model (distributed leadership) takes it for granted that in case of changes the leaders are needed at every level of the organizational culture or otherwise it will be impossible to "sell" the change to ordinary staff members and the whole program will be stopped at the highest level creating the resistance of those people to whom the changes refer. As Senge (2006) noticed “... companies which are able to maintain a significant change achieve it with a little participation of top leaders. It is better to look for people who are in the center of the processes generating the values-designing, producing, selling products, delivering services, talking with clients. Such people lead business and take in the right direction". In the star model, there is a conviction that every change needs a person who gives their name to it. This requires a strong authoritarian leadership concentrated on the highest level of the organizational structure.
} 


\begin{tabular}{|c|c|c|c|}
\hline & & $\begin{array}{l}\text { - Ways of measuring financial results; } \\
\text { - Selected elements of personnel function } \\
\text { (performance appraisals + trainings). }\end{array}$ & \\
\hline Transaction 2 & Moderate & $\begin{array}{l}\text { - Organizational structure; } \\
\text { - Technology; } \\
\text { - Brands integration; } \\
\text { - IT systems; } \\
\text { - Accounting procedures; } \\
\text { - Supply; } \\
\text { - R+D; } \\
\text { - Elements of personnel policy } \\
\text { (performance appraisals + trainings). }\end{array}$ & $\begin{array}{l}\text { - Range: partial integration; } \\
\text { - Level: moderate; } \\
\text { Pace: integration planned for the period } \\
\text { of three years; } \\
\text { - Integration activities visible already after } \\
100 \text { days after the acquisition and the } \\
\text { intensification in the second year of } \\
\text { existence in the merged structure. }\end{array}$ \\
\hline
\end{tabular}

Table 4 continued

\begin{tabular}{|c|c|c|c|}
\hline $\begin{array}{l}\text { Number of } \\
\text { transaction }\end{array}$ & $\begin{array}{l}\text { Level of } \\
\text { organizational } \\
\text { similarity }\end{array}$ & Areas which were integrated & Level, range, and pace of integration \\
\hline Transaction 3 & Low & $\begin{array}{l}\text { - Organizational structure; } \\
\text { - IT systems; } \\
\text { - Sales; } \\
\text { - Accounting procedures; } \\
\text { - Systems of managing financial results; } \\
\text { - Supply (partial integration); } \\
\text { - Selected elements of personnel function } \\
\text { (performance appraisals + } \quad \text { selected } \\
\\
\text { procedures of staff selection). }\end{array}$ & $\begin{array}{l}\text { - Range: partial integration; } \\
\text { - Level: moderate; } \\
\text { Pace: slow, with one year transition } \\
\text { period, planned for the period of four } \\
\text { years. }\end{array}$ \\
\hline Transaction 4 & Low & $\begin{array}{l}\text { - Organizational structure; } \\
\text { - IT systems (partial integration); } \\
\text { - System of financial results measurement; } \\
\text { - } \text { Impharmaceutical marketing; } \\
\text { future will lead to changes in the area of } \\
\text { personnel function (e.g., giving values to } \\
\text { different positions). In the acquired } \\
\text { company, there is a social contract which } \\
\text { significantly reduced the possibility of } \\
\text { implementing the changes in the field of } \\
\text { human resources management. }\end{array}$ & $\begin{array}{l}\text { - Range: partial integration; } \\
\text { - Level: moderate; } \\
\text { Pace: slow, planned for the period of } \\
\text { three to four years. }\end{array}$ \\
\hline Transaction 5 & Moderate & $\begin{array}{l}\text { - Organizational structure; } \\
\text { - IT systems (partial integration); } \\
\text { - System of financial results measurement; } \\
\text { - } \text { Pharmaceutical management; } \\
\text { - Supply; } \\
\text { aplements of personnel functions (selected } \\
\text { appraisals, trainings, and competences } \\
\text { management system), management by } \\
\text { objectives. }\end{array}$ & $\begin{array}{l}\text { - Range: partial integration; } \\
\text { - Level: moderate; } \\
\text { Pace: integration activities visible within } \\
\text { three first months. Main activities in key } \\
\text { areas implemented within } 18 \text { months. }\end{array}$ \\
\hline
\end{tabular}

In case of two analyzed companies, the profile of similarity was moderate. The dynamics of the integration activities implemented was higher than that in other cases. The visible integration activities were conducted within the first 100 days from the moment of the transaction. The key areas were integrated after 1.5-2 years of functioning in the post-merger structure. In each case, the integration had only a partial character.

A centralized model of integration was used creating a joint team for integration consisting of the representatives of both merging companies. Additionally, another common feature was the previous experience of CEO in the acquisition processes.

In case of the remaining three companies, the level of similarity in the analyzed areas was low. The 
strategy of functioning after the merger is usually based on the partnership model referring only to key areas. The dynamics of the integration activities implemented here was low.

\section{Conclusions}

The analyzed acquisitions in the pharmaceutical sector have horizontal character. Despite it, the analyzed companies-transaction partners have different business models, structures, and organizational cultures. While taking the decisions concerning the transaction these issues, as underlined by the participant of interviews, it was not taken into consideration, particularly the cultural dimension.

During the research, "the duality" of the organizational culture resulting from the parallel existence of two groups of employees (production and "R $+\mathrm{D}$ ") was often underlined.

The marginalization of the cultural aspects shows the belief that the organizational culture in pharmaceutical companies is poor; furthermore the transfers of personnel within the industry result in coping with the management practices and patterns of behavior (Pawlak, 2012). The evaluations of the "similarity of organizational profile" in the field of management style generally confirm it. It must be underlined that branch mergers are supposed to require a higher integration of structures, strategies, and management models. As the described research showed, after three years of functioning in the post-merger structures, the range of integration is low or moderate. In three analyzed cases, a long-term perspective is clearly visible, longer than three years. In the analyzed cases, no activities were undertaken which would result in the creation of the common identity of the transaction partners (Stankiewicz-Mróz, 2012).

\section{References}

Agrawal, A., \& Jaffe, J. (2000). The post-merger performance puzzle. Advances in mergers and acquisitions. Amsterdam: Elsevier.

Aniszewska, G. (2002). Proces integracji w fuzjach i przejęciach. Rola kultury organizacyjnej. In K. Moszkowicz and B. Olszewska (Eds.), Zarzqdzanie strategiczne w teorii i praktyce (pp. 23-29). Wrocław: Wydawnictwo Akademii Ekonomicznej im. Oskara Langego we Wrocławiu.

Barbour, R. (2011). Badania fokusowe. Warszawa: PWN.

Bengtsson, L., \& Larsson, R. (2012). Researching mergers \& acquisitions with the case study method: Idiographic understanding of longitudinal integration processes (Center for Strategic Innovation Studies [CSIR], Blekinge Institute of Technology, paper No. 4).

Boschma, R. A. (2005). Proximity and innovation: A critical assessment. Regional Studies, 39, 61-74.

Bower, J. L. (2004). When we study M\&A, what are we learning? In A. Pablo and M. Javidan (Eds.), Mergers and acquisitions. Creating integrative knowledge (pp. 235-244). Oxford, UK: Blackwell.

Coffey, J., Garrow, V., \& Holbeche, L. (2002). Reaping the benefits of mergers and acquisitions in search of the Golden Fleece. Oxford: Butterworth-Heinemann.

Cooke, P. (2006). Bliskość, wiedza i powstawanie innowacji. Studia Regionalne i Lokalne, 2(24), 21-22.

Czakon, W. (2010). Hipoteza bliskości. Przeglad Organizacji, 9, 16-21.

Epstein, M. (2004). The drivers of success in post-merger integration. Organizational Dynamics, 33, 174-176.

Habeck, M. M., Kröger, F., \& Träum, M. R. (2000). After the merger-Seven rules for successful post-merger integration. Edinburgh Gate, Westminster: Pearson Education Limited.

Hess, J. M. (1968). Group interviewing. In R. L. King (Ed.), Marketing and the new science of planning (pp. 193-196). Chicago: American Marketing Association.

Hunt, J. W. (1990). Changing pattern of acquisition behavior in takeovers and the consequences for acquisition processes. Strategic Management Journal, 11(1), 69-77.

Iwai, K. (2002). The nature of business corporation: Its legal structure and economics functions. Japanese Economics Review, 53, 243-273. 
Larsson, R., \& Finkelstein, S. (1999). Integrating strategic, organizational, and human resource perspectives on mergers and acquisitions: A case survey of synergy realization. Organization Science, 10(1), 1-26.

Larsson, R., \& Lubatkin, M. (2001). Achieving acculturation in mergers and acquisitions: An international case survey. Human Relations, 54(12), 1573-1607.

Menzel, M. P. (2006). Dynamic proximities. Towards a concept of changing relations. Proceedings from the 5th Proximity Congress, Bordeaux.

Miles, M. B., \& Huberman, A. M. (1994). Qualitative data analysis. An expanded sourcebook (2nd ed.). Beverly Hills, CA: Sage.

Pablo, A. L., \& Javidan, M. (2002). Thinking of a merger... Do you know their risk propensity profile? Organizational Dynamics, $30(3), 206-222$.

Pawlak, J. (2012). Fuzje i przejęcia jako strategia alternatywna dla rozwoju organicznego przedsiębiorstw—Badania długofalowych efektów ekonomicznych na przykładzie sektora motoryzacyjnego, niepublikowana praca doktorska (Wydział Nauk Ekonomicznych, Uniwersytet Warszawski, Warszawa).

Petuzzelli, A. M., Albino, V., \& Carbonara, N. (2009). External knowledge sources and proximity. Journal of Knowledge Management, 13(5), 301-318.

Rallet, A., \& Torre, A. (1999). Is geographical proximity necessary in the innovation networks in the era of global economy? Geo Journal, 49, 373-380.

Senge, P. (1998). Piqta dyscyplina. Teoria i praktyka organizacji uczacych się. Warszawa: Dom Wydawniczy ABC.

Stankiewicz-Mróz, A. (2012). Integracja potransakcyjna jako proces budowania tożsamości organizacji po fuzjach i przejęciach. Acta Universitatis Lodziensis. Folia Oeconomica, 276, 177-187.

Torre, A., \& Gilly, J. P. (2000). On the analytical dimension of proximity dynamics. Regional Studies, 34(2), 169-180.

Torre, A., \& Rallet, A. (2005). Proximity and location. Regional Studies, 39, 47-59.

Zeller, C. (2004). North Atlantic innovative relations of Swiss pharmaceuticals and the proximities with regional biotech areas. Economic Geography, 80(1), 83-111. 